\title{
Museerna och forskningen
}

\author{
Richard PETTERsson*
}

Title: The museums and their research.

Abstract: This article deals with the theme of research conducted at the museums, with a focus on state investigations, cultural politics and the internal development of the Swedish museal profession. The statistics and surveys that have been prepared on the theme of research at the Swedish museums all point in one directionthere is a lack of museum staff with professional research competence and the level of active research performed at the museums is generally very low. This article discusses these facts from a historic and museological point of view. The author claims that both museums and universities would benefit from a higher level of research being performed at the Swedish museums, especially when one looks at the nearly non-existent research about the exhibition as a arena for multi-lingual and multimodal communication.

Key words: Museums, museology, research, professionalization, education, commission to society.

Denna artikel utgår frän temat forskning på museer, $i$ relation till dels statliga missiv och styrdokument, dels sett till aspekter på den museala professionens interna utveckling. Författandet är utfört inom ramen för forskningsprojektet "Museet, besökaren och utställningen", finansierat via Vetenskapsrådet. Vi är ett tiotal forskare från olika länder, fakultet och discipliner, som bland annat forsöker tolka och beskriva uppkomsten av en eventuell "museikultur" som diskursivt styr museernas interna agendor, liksom utställningars epistemologiska utgangspunkter. Ett led $i$ detta är exempelvis att titta närmare på hur synen på vetenskap och forskning kan te sig på kulturhistoriska museer, såväl i Sverige som pà kontinenten. Föreliggande artikel tar sin utgangspunkt $i$ det sist- nämnda temat, med huvudsakligt fokus på förbållanden inom den svenska arenan.

"Kulturell demokrati är ingen trogen följeslagare till den politiska och ekonomiska. Min tro är att fackföreningen liksom kooperationen [...] under 80-talet kommer att ta den kulturella demokratin på allvar. Om så sker krävs föga fantasi att förstå innebörden - en slags kulturrevolution som kommer att skaka museerna i deras grundvalar [...] Det kommer kanske att krävas museer med en annan inriktning. Det kommer kanske att krävas ett annat museifolk."

Detta inledande citat härrör från den i Sverige kände museimannen Erik Hofrén - citatet trycktes i en debattskrift 1978. Hofrén som se- 
dan under 1980-talet själv var drivande kraft bakom skapandet av arbetets museum i Norrköping och som under 1990-talet var t.f. professor i museologi vid Umeå universitet, fick så småningom rätt $\mathrm{i}$ sin framtidsvision. Den "kulturella demokrati" som apostroferades avsåg visionen att ge tidigare underrepresenterade samhällsgrupper tillträde och synlighet på den offentliga kulturella arenan och då inte minst på museerna. Men den museala "kulturrevolution" Hofrén anade har tagit tid, den tog i egentlig mening fart först vid andra halvan av 1990-talet, och då med andra drivande aktörer än specifikt fackföreningar och kooperationen. Processen pågår ännu i högsta grad - kanske är det mer lämpligt att beskriva det hela som en evolution, ett långsamt spårbyte för en verksamhet som har sin upprinnelse $\mathrm{i}$ en annan samhällsform än den som nu är aktuell.

Hofréns vision förekom bland mängder av andra valda citat i debattskriften Samla, varda, visa - eller något mer?, författad av Göran Rosander och utgiven via Statens kulturråd samt Svenska museiföreningen; året var som sagt 1978. Rosanders debattskrift var medvetet provokativ och den debatterades. Fortfarande 30 år senare känns många frågor och slutsatser högst aktuella. ${ }^{2}$

En central del i Rosanders utläggningar rörde museipersonalens kompetens. Han talade om museet som den "fria akademin" och forskningen inom museet som en huvuduppgift vid sidan av att samla, vårda och visa. Skriften kom i en tid av musealt och kulturpolitiskt uppbyggande. Den första kulturpropositionen hade klubbats igenom 1974; länsstyrelserna hade fătt sina kulturminnesvårdsavdelningar med en länsantikvarie i spetsen; Statens kulturråd hade formerats och museernas ekonomi var stadigt stigande, nu med införandet av så kallade basbelopp bakom de statliga anslagen.
Detta var före konjunktursvängningen vid 111 början av 80-talet, då anslagskurvorna skulle komma att brytas nedåt igen. Trots konsolideringen av kultursektorn var museerna generellt oftast fattiga. Men möjligheterna fanns och det ljusnade som sagt i horisonten. Det gällde i det läget att staka ut vägen; vilka var museernas samhällsuppdrag; vad skulle man hålla på med, och varför? Denna artikel fokuserar på en väsentlig redan nämnd aspekt i detta: museipersonalens akademiska kompetens och möjlighet till forskning. Men att enbart utgå från frågan om forskning bedrivs på landets museer eller inte, vore ett alltför snävt tema för vad jag här söker beskriva. Temat forskning på museer vetter mot den bredare utgångspunkten: museipersonalens generella kompetens. Och kompetensfrågan vetter i sin tur mot den än bredare aspekten på själva samhällsuppdraget. Jag har därför även tagit med kulturpolitiska och utredningsrelaterade aspekter till temat forskning på museer, för att söka förankra resonemangen i en bredare museirelaterad, kulturpolitisk och idéhistorisk bakgrund.

Merparten av debatt och utredande i temat som har förts och dokumenterats under 1900och 2000-talet har rört kompetensfordringarna rörande museernas chefsposter. Kompetensfordringarna visavi yrkesposter längre ner i den museala hierarkin är generellt sett yrkesspecifika: en anställd arkeolog bör vanligen ha en akademisk examen i sin CV, medan det fordras en annan kompetensprofil för exempelvis en snickare i museets verkstad. Det skulle därför föra alltför långt och bli en ohanterlig redovisning att driva resonemang kring kompetensfordringarna för varje yrkeskategori inom ett museum. Personalstaben vid landets museer består av en brokig och bred skara yrkesprofiler. Beroende på museets storlek kan inom samma väggar, utöver utställnings- och kultur- 
112 miljöavdelningar, rymmas landskapsantikvarie, ljus- och installationstekniker, vaktmästare, fotograf, webansvarig, marknadsförare, snickare, konservator, bibliotekarie, etc.

\section{FORSKNINGSKOMPETENT MUSEIPERSONAL?}

Större officiella museer har alltid varit institutioner där forskning (och utställningsverksamhet $)^{3}$ har bedrivits i anknytning till samlingarna. En översikt om forskning på museer i Sverige skulle därför kunna ta en utgångspunkt i det offentliga öppnandet av Kungligt museum 1794, men jag väljer i denna artikel att börja i mer samtida sammanhang, med den sist utförda statliga undersökningen om svenskt museiväsen från 1994 - mina historiska tillbakablickar kommer uteslutande att behandla 1900-talet.

Jag har som sagt valt att fokusera på temat "forskning på museer" som en intressant och omdebatterad ingång för analys. Valet av tema är ingalunda vare sig nytt eller obehandlat i andra sammanhang och det kan ur en statistisk synvinkel till och med anses ovidkommande, då museipersonals egen forskningsverksamhet bevisligen är en marginalföreteelse i förhållande till övriga samlande, ordnande, vårdande och visande funktioner. Den i dagsläget senast genomförda statliga utredningen över museernas övergripande verksamhet härrör från 1994 och publicerades som betänkandet Minne och bildning: Museernas uppdrag och organisation (1994: 51). Där angavs att de svenska museerna totalt sett ägnar högst $4 \%$ av sina resurser till forskning. Jämförelserna mellan länsmuseerna och de stockholmsbaserade ansvarsmuseerna tydliggör procentsatsen: "Vid länsmuseerna ägnas forskningen i genomsnitt 0,78 årsverk per museum och år, och vid Nordiska museet 8,4 (av 253 anställda i alla kategorier).”4
DIK Museimannaförbundet genomförde år 2004 en uppföljande undersökning om forskning och forskarkompetens på museer. Möjligen kan man av svaren på deras enkät dra en slutsats om marginellt högre frekvens av forskning på museerna under 2000-talet, men statistiken försvåras av faktumet att det råder en begreppsförvirring kring själva termen forskning - vissa museer gör exempelvis ingen tydlig skillnad "mellan undervisning (förmedling av befintlig kunskap) och forskning (systematiskt framtagande av ny kunskap)".5 Jag återkommer till denna begreppsförvirring framöver.

Forskningen vid museerna är alltså statistiskt sett en marginalverksamhet och kan därmed tyckas vara en bisak gentemot övriga museala göromål, men det vore ur flera synvinklar ett misstag att dra en sådan slutsats. Museibetänkandet från 1994 betonade exempelvis med eftertryck att museernas samhällsuppdrag är liktydigt med att utveckla och förmedla kunskap, samt att därmed bidra till bildning för medborgarna. ${ }^{6}$ Att utveckla kunskap för att bidra till besökarens bildning innefattar kanske inte med automatik att förmedlarna ska ägna sig åt forskning, men väl att museipersonal bör vara källkritiskt skolad och väl förtrogen med den praktik, terminologi och forskningsdiskurs som leder fram till historisk kunskap. ${ }^{7}$ Att museipersonal på åtminstone ledande chefsposter ska äga forskningskompetens var därför tidigt en målsättning för sakkunniga bakom utredningar och styrdokument om statlig minnesvård under 1900 -talet. ${ }^{8}$ Denna ambition följdes även upp, som vi ska se nedan, i mer nutida utredningar och propositioner.

Forskning och, kanske framförallt, forskningskompetens på museer är inte och har aldrig varit en bisak. Det antikvariska yrket är en humanistisk profession, även om den vardagli- 
ga praktiken på museerna ofta skiljer sig från den motsvarande akademiska. Det antikvariska huvuduppdraget är mer sällan att forska framför att undervisa och/eller ställa ut och därmed kommunicera olika värderingar, uppfattningar och helhetssyner kring natur- och kulturhistoria. Men det säger sig självt att museernas upparbetade praktik att förmedla tolkningar och perspektiv genom artefaktbaserade utställningar, i sig förutsätter historisk, didaktisk, och kulturteoretisk kunskap. Museal representation är sprängfylld med kulturteoretiskt teori och metod, liksom även ibland fördomar, etnocentrism och aningslöshet - det existerar ingen "neutral" utställning. Museets nisch är att använda artefakter för att förmedla olika valörer av kunskap och nyfikenhet; vanligen dock kompletterat med texter och/eller audiovisuella hjälpmedel. Forsk-ningskompetens som en grund för att förstå innebörden möjligheter och svårigheter - i denna praktik, är därför väsentligt.

Trots detta har kravet på forskningskompetens för högre poster inom museerna i Sverige släppts under andra delen av 1900-talet. Den redan påtalade etnologen och musiemannen Göran Rosander, ${ }^{9}$ som för museiutredningen 1994 publicerade en omfattande undersökning om forskningens dåvarande status vid Sveriges museer, konstaterade frankt: "Nästan ingenstans torde forskarexamen numera krävas för vissa tjänster." ${ }^{10}$ Vidare konstaterade han att museernas roll för den universitetsbedrivna forskningen i sin tur tycks ha marginaliserats. Museerna fungerar numera i huvudsak som "leverantörer av data till den akademiska forskningen", menade Rosander. ${ }^{11}$ Här anspelar resonemanget på att museerna tidigare fungerade som forskningsfilialer inom anknytande akademisk forskning - huvudsakligen då etnologi, konstvetenskap och arkeologi.
Orsaken till forskningens tillbakagång vid 113 de svenska museerna anger Rosander utan omsvep vara det paradigmskifte som skedde inom kulturhistorisk forskning från 1960-talet och framåt. ${ }^{12}$ Den statistiska och faktapositivistiska forskning som kännetecknade majoriteten av 1900-talets etnologiska och arkeologiska forskning, hade passat museerna som hand i handske. Med ett visst mått av förtret tycktes Rosander konstatera att museernas personal och verksamhet numera inte kunde, eller önskade, hänga med de nya forskningsinriktningarna:

Huvudorsaken till marginaliseringen torde få tillskrivas det nya humanistiska forskningsparadigm som bröt igenom på 60-talet, då positivismen fick vika för strukturalism, hermeneutik och fenomenologi och en forskning som ofta arbetade med teoretiska modeller. Museernas givna triumfkort, faktapositivism grundad på realstudier, blev med ens gammalmodigt. Museiforskningen och den akademiska forskningen skilde lag. Den moderna västerländska människan står nu centrum för kulturvetenskaperna, ej allmoge och 'naturfolk' - något som svär mot de kulturhistoriska museernas klassiska uppläggning och $80 \%$ av föremålsbeståndet. ${ }^{13}$

Rosander fortsätter sin utläggning med att, som en andra förklaring till forskningens tappade status, påpeka att museitjänstemännen i äldre tid inte hade tillnärmelsevis samma krav på sig från "samhället" som de har nu - förr hade museichefen "tid att skriva". Sistnämnda påstående har sannolikt fog för sig, men bör samtidigt tas med nypa salt. Att döma av mina tidigare studier kring landsantikvariernas kompetensfordringar och arbetsvardag, från 1930 talet och framåt, ${ }^{14}$ ställer jag mig tvivlande till att den museala arbetsvardagen då egentligen erbjöd mer än marginellt större utrymme till forskningsstudier än senare. 
114 Rosanders hänvisning till det nya forskningsparadigm som lämnat museerna bakom sig är desto mer intressant. Strukturalistisk och senare konstruktivistisk teori, bröt mot museibranschens institutionella uppbyggnad kring bevarande och vård av artefakter. Museets traditionella roll att samla och vårda ger institutionen en inneboende tröghet att ändra sin insamlings- och bearbetningspolicy - museimagasinens fysiska existens och taxonomiska principer för organisering är exempelvis en faktor som inte ändras i en handvändning.

Med detta sagt kan man kanske tro att ingen forskning alls bedrivs runt landets museer och att museernas antikvarier har en låg utbildningsnivå. Riktigt så illa är det dock inte. Rosanders undersökning från 1994 kunde konstatera att merparten museianställda hade fil. kand. examen vid mitten av 1990-talet, 116 personer hade doktorsgrad, 31 av dem hade docentkompetens, och femton ansågs vara professorskompetenta - dock anges inte den totala summan museipersonal dessa uppgifter ska relateras till! (Troligen omfattade studien drygt 800 museitjänstemän, likt en tidigare studie som genomförts $1988 .^{15}$ ) DIK-förbundets undersökning från 2004, som hade ett än bredare svarsunderlag, visade att landets museer, borträknat det Naturhistoriska Riksmuseet, hade totalt 130 fast anställda med forskarutbildning. ${ }^{16}$ Dessa siffror borde stämma till eftertanke, inte minst i relation till uppgiften om att endast runt $4 \%$ av museernas generella budget nyttjas till forskning.

Undersökningarna visar samstämmigt att merparten anställda vid statligt understödda museer har akademisk examen och här och var finns således även doktorer, docenter och någon enstaka professor (dock långtifrån på alla museer). Men som DIK-Museimannförbundets undersökning från 2004 visade på, är det kanske inte alltid i tillgången till forskningskompetens som knuten sitter: "Problemen handlar emellertid inte primärt om brist på forskarkompetens utan snarare om den låga forskningsaktiviteten, forskningens bristande organisation och planering samt inte minst den framtida kompetensförsörjningen." 17 Beträffande det sistnämnda så visade undersökningen 2004 att "nära hälften av museernas forskarkompetenta personal kommer [...] att gå i pension under de närmast 10 åren." ${ }^{\prime 18}$

Kompetensen tycks alltså i vissa fall finnas (dock mindre frekvent på länsmuseerna än på de stora centrala museerna) - vad som saknas är tiden och den organisatoriska möjligheten att ägna sig åt forskning. ${ }^{19}$ Det finns flera orsaker bakom detta, en vetter mot museernas krassa ekonomi. Forskning ingår normalt inte i museernas driftsbudget - forskarutbildad personal måste därför söka forskningsmedel från de gängse forskningsråden, i tävling med forskare från universiteten. Med tanke på den enorma konkurrens som numera råder om dessa forskningsmedel, är det knappast förvånande om museianställda sällan tilldelas anslag. Sett från den synvinkeln är det imponerande hur stor produktion museerna, trots sin ringa satsning på forskning, ändå genererar i form av broschyrer, utställningskataloger, böcker, artiklar och konferensbidragande. ${ }^{20}$ Och kvalitén tycks inte vara generellt undermålig.

Museiutredningen från 1994 innehöll en evaluering av vetenskapliga och populärt hållna skrifter från statliga och statsunderstödda museer i Sverige. Undersökningen genomfördes av professor Tryggve Solhaug vid Norges Handelshögskola, och hans slutsatser var kort sagt de att publikationerna visserligen stundom visade prov på teoretisk aningslöshet och okritiskt anammande av begrepp och kategorier, men att forskningen generellt inte höll lägre 
nivå än de alster som produceras vid universiteten. ${ }^{21}$ Forskningens kvalitet är med andra ord inte heller det problemet i sammanhanget - problemet ligger som nämnt i att forskningen inte förekommer $\mathrm{i}$ den utsträckning den borde, samt att den ofta inte har någon organisatorisk uppbackning vid museerna.

Parallellt med museets roll för dokumentering och arkivering finns också det visande, eller förmedlande, uppdraget. Det är genom museernas utställningar som eventuella förändringar på det teoretiska planet synliggörs för en allmänhet. Kulturpolitikens insteg från 1960-talet har påskyndat museernas arbeten för samhällstillvändhet, vilket i sin tur har medfört ett ökat fokus på museets roll som pedagogisk och kunskapsspridande institution. Museerna har manats att starkare uppmärksamma underrepresenterade och tidigare osynliggjorda samhällsgrupper, liksom även öka samhällsdialogen och bredden på verksamheten. Kort sagt har allt större fokus riktats mot att förnya och komplettera museernas pedagogiska uppdrag, med nya krav på relativism, mångkulturella perspektiv och fokus på underrepresenterade samhällsgrupper. Detta borde i sig förutsätta ett ökat krav på teoretisk medvetenhet bland museernas personal och därför en ökad prioritering på egen forskning och utbildning inom driftsbudget - men statistiken visar, paradoxalt, på något annat.

\section{VAD SÄGER UTREDNINGAR OCH STYRDOKU- MENT OM FORSKNING PÅ MUSEER?}

Kulturpolitikens framväxt förändrade museernas vardag. ${ }^{22}$ Konsekvent har målsättningen om en ökad demokratisering av kulturen varit en ledstjärna. Göran Rosander hade själv år 1978 i den inledningsvis nämnda skriften om musernas kulturpolitiska roll i Sverige, angett att museets samhällsroll kanske i första hand 115 borde vara service gentemot besökarna. Som en medvetet spetsig provokation skrev han då: "Att vara serviceinriktad är en viktigare egenskap för en museiman än forskningsintresse, pedagogisk kunskap och administrativ förmåga" Och vidare: "Också icke-akademisk personal ska ha inflytande över forskningsinriktning och utställningsprogram." ${ }^{33}$ Då Rosanders skrift blev både läst och diskuterad bland medlemmar i Svenska museiföreningen, kan man undra om Rosander inte själv hade bidragit till att bädda för den situation av forskningstorka vid museerna han 16 år senare kritiserade.

Museibetänkandet 1994 angav i sin samlade definition för museibegreppet också en tydlig markering bort från branschens tidigare krav på forskning vid museerna. Jag citerar här deras definition med de sakkunnigas efterföljande kommentar:

[Definitionen:] Museet samlar in, dokumenterar, bevarar och levandegör föremål och andra vittnesbörd om människors kultur och miljö. Det utvecklar och förmedlar kunskap och bjuder upplevelser för alla sinnen. Det är öppet för allmänheten och medverkar i samhällsutvecklingen. Museets syfte är bildning för medborgarna.

[Kommentaren:] Definitionen skiljer sig från den gällande [1986 års museiutredning] genom att inte specificera vad de som arbetar vid museet har för utbildning och hur de är anställda, den ställer inte krav på att det ska bedrivas forskning och det är möjligt att museet är öppet en mindre del av året. Med den här definitionen blir Sverige i ett slag ca 500 museer rikare, museiverksamheten blir mera decentraliserad och når i större utsträckning människor där de arbetar och bor. Utredningen betonar också museernas bildningsuppgift: de är till för att tjäna samhällets utveckling. ${ }^{24}$

Utredningens museidefinition och vidhäng- 
116 ande kommentar är försåtligt framställd. Anmärkningsvärt är att de sakkunniga, som enligt dem själva hade hört mer än $1000 \mathrm{mu}$ seianställda runt landet, uttrycker sig gillande för att sänka de professionella kraven på ett museum. Man riktade sig mot den svenska definition som senast 1986 hade betonat "forskning och dokumentation" som ett centralt musealt verksamhetsområde. ${ }^{25}$ Branschens dåvarande och fortfarande aktuella museidefinition, kan anses syfta på att ett museum bör ägna sig åt forskning. Den internationella definitionens punkt 3 lyder då som nu: "A museum is a non-profit, permanent institution in the service of society and its development, open to the public, which acquires, conserves, researches, communicates and exhibits the tangible and intangible heritage of humanity and its environment for the purposes of education, study and enjoyment." ${ }^{26}$ Men museiutredningen valde i sin hänvisning till ICOM:s definition att översätta "researches" med den svenska termen "undersöker". Att undersöka något har en betydligt vagare och mindre förpliktande betydelse än att motsvarande mena sig forska kring en företeelse. ${ }^{27}$ Museiutredningen ville uppenbart inkludera den växande skaran av arbetslivsmuseer som ofta drivs ideellt och av lekmän. Konsekvensen blev att hänvisningar till museipersonalens utbildningsnivå, samt museiinstitutionens grad av tillgänglighet (öppethållande), helt utelämnades i resonemangen kring gällande museidefinition.

Tidigare svenska museidefinitioner beskrevs som konservativa och exkluderande - museiutredningen uttryckte sitt starka gillande för att den nya definitionen i ett slag skulle öka den officiella statistiken över svenska museer, från i antal 210 till totalt 750. Värdeladdade ord som "vitalitet", "samhällets minne" och "med- verkar i samhällsutvecklingen" underbyggde den oklart motiverade omdefiniering som föreslogs. ${ }^{28}$ Att 500 fler officiella museer också hade inneburit en tredubbling av de museer som hade kunnat göra anspråk på statens begränsade bidrag och stöd, berördes endast flyktigt i utredningen.

Det demokratiska värnandet om de nya museerna och deras samhällsvärde skapade vankelmodiga ståndpunkter i utredningen. På ett ställe konstaterades det att: "Varje enskilt museum behöver inte bedriva forskning och vara lett av museiutbildad personal. Det viktigaste är att det verkar för samhällets utveckling och ställer kunskap till förfogande." ${ }^{29}$ Längre fram, när utredningen rört sig in på området kompetens och utbildning för landets museipersonal, konstaterade sakkunniga emellertid att rådande utbildningar för museernas personal var otillräckliga: "De ämnen som av tradition ansetts nog meriterande för att få anställning på ett museum - konsthistoria, etnologi, arkeologi - och som de flesta i museisystemet för har i sin grundexamen, räcker inte. Museipersonalen, den blivande och den som nu är ute i museerna, behöver utöver dessa ämnen en gedigen museologisk kunskap om den institution den skall verka i." ${ }^{30}$ Som yrkesverksam museolog kan jag inte annat än applådera det sista, men det är uppenbart att utredarna vacklade $\mathrm{i}$ frågan om museipersonals teoretiska kompetens. Museiutredningen, vars ledamöter hade en blandad politisk sammansättning, togs fram på endast ett år från start till färdigt betänkande. Möjligen kan det förklara utredningens tillkortakommanden och motsägelser.

Betänkandet underbyggde regeringens stora satsning på "SESAM-projektet för bevarande och tillgängliggörande av kulturarvet" året därpå. Men utöver denna mångmiljon- sats- 
ning på omhändertagande och registerföring av museimagasinens artefakter, resulterade inte utredningen i någon revidering av museernas samhällsuppdrag eller organisation. I regeringens proposition Kulturpolitik 1996/96:3 angavs inga intentioner att diversifiera museidefintionen eller minska professionalismen, tvärtom angavs ett behov av att bredda museipersonalens kompetens, detta inkluderade forskningsuppdraget: "Forskning skall naturligt anses ingå i museiuppdraget." ${ }^{1}$ Någon specificering av vad detta med forskning mer konkret innebär och förutsätter för den museala verksamheten angav dock inte propositionen.

Bristen på specificering om vad som utmärker den museibaserade forskningen kännetecknar samtliga statliga utredningar och styrdokument kring museernas forskning under de senaste decennierna. Regeringens i skrivande stund rykande färska proposition om forskningspolitik anger i det närapå 300 sidor långa dokumentet en mening som kopplar till museernas forskningsverksamhet: "Kulturarvsinstiutionernas forskning är till övervägande del knuten till samlingarna, vilket gör att deras roll som kunskapsuppbyggare och kunskapsbärare är central och knappast kan ersättas av andra."32 Kännetecknande för forskning på museer är alltså att forskningen utgår från institutionens samlingar - inte från utställningarna. Huruvida denna forskning leder till andra slutsatser och resultat än motsvarande universitetsbaserad forskning, specificerar propositionen inte.

Som parallell till de svenska förhållandena kan kort nämnas att den museala forskningen också i skrivande stund diskuteras i Danmark. Här förefaller det så att utdelning av statliga medel för forskning på museer avses kopplas till kvalitetsmätningar (så kallad benchmar- king). Anslagens storlek och frekvens kommer att avgöras genom statistiskt mätande och bedömning av huvudsakligen skrivet material, i relation till det som tidigare producerats inom respektive institution. Företrädare för museibranschen har i denna situation framhållit att forskningen på museer ofta får sin specifika karaktär genom att vara kopplad till samlingarna. Signe Margarete Eberhart Sörensen vill i en artikel för Nordisk museologi gå steget längre och menar att valideringen inte enbart bör kopplas till publikationer utan även till utställningsverksamheten. ${ }^{33}$ Hur en validering av museernas utställningsverksamhet konkret ska kunna organiseras och implementeras inom ramen för ett statligt anslagssystem, vidrör Eberhart Sörensen dock inte. Bortsett från problemen att mäta museernas forskningskvalitet, förefaller det dock så att forskning på museer har en starkare ställning i Danmark och att större museer regelmässigt innefattas av forskningstjänster, forskningschefer och råd. ${ }^{34}$

Den svenska Museiutredningen 1994 förhöll sig dock som sagt påtagligt defensiv gentemot professionaliseringsanspråk och nyttjade istället flitigt $\mathrm{i}$ tiden moderiktiga hänvisningar till att museerna utgör "samhällets kollektiva minne" och att museet "utvecklar och förmedlar kunskap och bjuder upplevelser för alla sinnen”, som angivelser för museets särart. Innebär detta att forskning bör bedrivas på museer? Det är här hög tid att kommentera själva syftningen i hänvisandet om "forskning på museer”.

OM FORSKNINGSBEGREPPET I RELATION TILL MUSEAL VERKSAMHET

En grundläggande fråga (med vidhängande följdfråga) måste ställas: Vad innebär egentligen 
118 termen "forskning", och varför bedrivs denna verksamhet bevisligen sparsamt runt landets museer? Göran Rosanders undersökning till betänkandet 1994 gav en utarbetad förklaring. Han inleder med att konstatera att det har gått inflation i begreppet "museiforskning" - rutinmässig insamling av data och material i fält benämns inte sällan som forskning. Detta har sin orsak i det tidigare nämnda arvet av positivistiskt inriktad faktainsamling. Enligt Rosander tycks termen "dokumentation" ha etablerats inom museisektorn först vid 1970-talet, som benämning för insamlande och registrerande av information av olika slag. ${ }^{35}$ Tidigare hade faktainsamlande, inordnande och katalogisering, oproblematiskt kategoriserats som "forskning". Hållningen förstärktes och bekräftades av det kulturhistoriska paradigm som var legio inom universiteten fram till slutet på 1960-talet, och som fortsatte inom museerna längre fram i tiden. Rosanders poäng är att skillnaden mellan dokumentation och forskning fortfarande vid 1990-talet inte var tydlig bland landets museipersonal. Argumentet relaterade till det som på senare tid har benämnts som "den kulturella vändningen" - d.v.s. praktiken att gå från att betrakta "kultur" som en faktisk materialiserad och genom historien iakttagbar storhet, till att syfta på "kultur" som grupprelaterade sociala processer. ${ }^{36}$ Denna genomgripande "vändning" tycks, av begripliga skäl, ha tagit tid på sig att slå igenom på museerna.

Vilka kriterier bör då vara uppfyllda för att numera klassa en verksamhet som forskning? Den frågan är inte enkel att besvara. Rosandet påtalar i museiutredningen att man visserligen bör skilja dokumentation från forskning, men att somlig dokumentation ändå faktiskt bör klassas som forskning:

Är dokumentation också forskning? Nej, inte i nor- malfallet. Mycket sker rutinmässigt, är ett led i museernas uppgift att samla data, som kanske kommer till användning om femtio år - eller aldrig. Sker däremot dokumentationen som ett led i en vetenskaplig process, med uttalade hypoteser och frågeställningar, måste det klassificeras som forskning. ${ }^{37}$

Grundförutsättningar för forskning är alltså, med Rosander, uttalade hypoteser och frågeställningar. Tilläggas bör också att de slutsatser som dras från dessa frågeställningar ska vara prövbara, de ska vara sakligt underbyggda och källmaterialet ska vara identifierbart.

Går vi djupare in på vad detta i sig innebär och förutsätter hamnar vi i disciplinen vetenskapsteori. Hyllmeter av litteratur är skrivet om och kring kärnfrågan: vad är vetenskap. Frågan vad vetenskap i sin essens är, är i själva verket ett av den västerländska filosofins grundteman med solid koppling bakåt till antikens skriftställare. En vanlig utgångspunkt bland universitetsutbildningarnas grundkurser är dock att ta utgång från vetenskapsfilosofen Carl Poppers devis om att vetenskapliga utsagor ska vara prövbara, eller kanske rättare "falsifierbara". Vetenskaplig kunskap ska bygga på systematiserad och bearbetad dokumentation av olika slag, den ska dessutom utgå från någon form av hypotes om det som undersöks, och slutligen ska slutsatserna vara möjliga att vederlägga, att falsifiera. ${ }^{38}$ Religiösa uppfattningar i stil med att en transcendent gudomlighet ligger bakom skeden i vår tillvaro, kan inte prövas - de är därför inte vetenskapliga. Sakupplysningar i stil med att lövkratta X innefattar tolv pinnar av ett specifikt träslag är heller inte i sig vetenskap, då de inte förutsätter någon specifik hypotes eller syntetisering av fakta, utöver empirisk iakttagelse. Inte heller är det vetenskap att ge sakupplysningar i stil med att det $\mathrm{i}$ museala samman- 
hang har samlats in $Y$ antal krattor av sagda typ från socken $\mathrm{Z}$ inom Sörmland. Men om man extrapolerar dessa fakta till en kulturteori om Sörmlands jordbrukssamhälle, där krattorna ingår som ett element bland andra - då är man inne på vetenskaplig aktivitet, förutsatt att man redovisar den teoretiska utgångspunkt där krattorna är den del av hypotesen om sörmländsk agrarkultur.

Det scenario jag just, schablonartat, har återgett var i själva verket ett av folklivsforskningens kungsteman under decennier lett av forskare som Sigurd Erixon med flera. ${ }^{39}$ Oändlig möda lades ner på att kartografiskt pricka in förekomsten av olika artefakttyper, liksom också seder och bruk, på en sverigekarta. Syftet var att hitta mönster och att, med naturvetenskaplig exakthet, identifiera och inringa svenska kulturområden och kulturgränser. Dillemmat för dessa fältforskare var att de som regel inte - vare sig för sig själva eller utomstående - tydliggjorde de vetenskapliga utgångspunkterna för tolkningen. Vad kännetecknade den förmenta "kultur" som låg till grund för karterandet? Det faktapositivistiska forskningsideal som rådde avtvingade sällan forskarna något tydliggörande. Faktainsamlandet och statistikskapandet blev ofta en aktivitet i sig nog (eller rättare - det var vetenskap) fram till 1960- och 70-talens nämnda paradigmskifte.

Men, allteftersom höll det inte längre måttet att sväva på målet kring vad kartläggning av exempelvis husknutsstyper i Västerbotten hade för roll inom ramen för en övergripande kulturhistorisk forskning. Med strukturalismen, fenomenologin, och senare konstruktivismen, omformulerades utgångspunkten omedelbart till den övergripande frågan: finns det egentligen en västerbottnisk, sörmländsk, eller skånsk "kultur"!? Och vad menar man i så fall med "kultur" i det fallet? (Frågorna 119 skulle numera även följas med: vilken roll har forskaren/-na, liksom uppgiftslämnarna, för skapandet av uppfattningen om denna "kultur".) Den äldre generationen forskare hade visserligen haft den 'stora frågan' om svenskt kulturskick för ögonen hela tiden, men undvikt att definiera den som katten kring het gröt $\mathrm{i}$ väntan på att de samlade delstudierna (likt de om husknutstyper) skulle ge ett entydigt svar. Problemet var bara att detta tillstånd av syntetiserad visshet aldrig infann sig - det fanns alltid nya artefakttyper att kartlägga och det blev aldrig rätt tillfälle att sammanställa; att genomföra den förlösande analysen. För att fullfölja mitt resonemang och därför återigen uttrycka mig schablonmässigt: Inför paradigmskiftets nya teoretiska krav, kastade de oftast etnologiskt och/eller arkeologiskt utbildade musei-/arkivforskarna generellt in handduken, som Rosander påpekat ovan. Kvar blev faktainsamlandet, bearbetandet och systematiseringen - den teoretiska tillämpningen fick andra, läs universiteten, ta hand om.

\section{MUSEIKULTUREN}

Museiyrket har för svensk del en drygt hundraårig historia av professionalisering när detta skrivs. Svenska museimannaföreningen bildas 1906 och får en närmast fackligt professionell utformning från tidigt 1930-tal. Föreningen klubbar år 1933 igenom så kallade normalinstruktioner för de nya länsmuseernas chefer: landsantikvarierna. ${ }^{40}$ Min hypotes är att det under 1900-talet har formerats en specifik "museikultur" som har betingats av ett flertal interna faktorer, och även förändrats $i$ takt med samhället och utbildningsväsendet.

Jag har påtalat det paradigmskifte inom kulturteoretisk forskning som inträffar vid 
120 1960-talet. Utgår man från de museala kärnämnena etnologi och arkeologi, är det uppenbart att museerna och universiteten gick hand $\mathrm{i}$ hand fram till denna tidpunkt. Från början av 1900-talet etableras såväl arkeologi som folkminnesforskning som discipliner vid svenska universitet. ${ }^{41}$ Folklivsforskningen i Stockholm under Nils Lithberg och senare Sigurd Erixon gavs också akademisk status, men den så kallade Hallwylska professuren var direkt kopplad till Nordiska museets institut för folklivsforskning. ${ }^{42}$ Nordisk och jämförande fornkunskap (arkeologi) undervisades av Knut Stjerna och Oscar Almgren med start vid Uppsala universitet. En majoritet av studenterna blev efterhand framträdande forskare och museitjänstemän. Många folklivsforskare hade, som exempelvis Sigurd Erixon, inlett sina karriärer med studier i nordisk och jämförande fornkunskap.

Forskningen var till sin karaktär inventerande och föremålsinriktad. ${ }^{43}$ Till en början handlade det om räddningsaktioner - det gällde att snabbt samla in och uppteckna alla de kulturföreteelser man uppfattade vara på väg att försvinna med moderniseringen av samhället. Det insamlade hamnade i arkiv och magasin, oftast på museer, och forskningen bedrevs i stor utsträckning med utgångspunkt från materialet. Eftersom forskningen var baserad på kartering och statistik, skapades också den logik som formerade "luckor" i materialet. Målet var att nå "fullständiga" serier av såväl artefaktkategorier som insamlade sägner etc. ${ }^{44}$

Här etableras därför under decennier en slag normalvetenskap för artefaktrelaterad forskning, som tillslut bryts i och med 1960 och 70-talens paradigmskifte inom kulturvetenskaperna. Med nya hermeneutiska, strukturalistiska och antropologiska kulturteorier, var inte längre inventering, kartografering och statistiskt ordnande av artefakter att betrakta som fullvärdig kulturforskning. Stor del av det som tidigare uppfattats som forskning, "degraderas" nu till dokumentation. Och parallellt med allt detta omvandlas museernas publika uppdrag. Länsstyrelsereformen 1976 flyttade mycket av museernas yttre kulturminnesvård till de nya länsantikvariernas kulturminnesvårdsavdelningar, även om museerna ändå lyckades behålla en del inventerande och rådgivande funktioner. ${ }^{45}$

Museisverige har expanderat markant sedan mitten av 1970-talet. Nya tjänster och museer har vuxit fram. ${ }^{46}$ Parallellt med detta har samhället och kulturpolitiken förändrats. Vid början av 1900-talet hade de enskilda museianställda stor betydelse för hur museisektorn skulle komma att utformas. Relativt få kunde på heltid ägna sig åt museiyrket och/eller den museianknutna forskningen. Museimännen - för det var oftast män på de ledande posterna - hade därför möjlighet att hålla sig underrättade om branschen. Nätverken sträckte sig regelmässigt även internationellt; svensk museiväsen följde i linje efter tysk, fransk och engelsk förlaga.

Den svenska statens åtagande gentemot museisektorn var fram till mitten av 1970-talet begränsad. Statliga fondmedel och så småningom lönemedel gav en viss stabilitet, men det är knappast djärvt att anta att museisektorn huvudsakligen betraktades som en tärande, mer än en närande verksamhet. En kulturnation värt namnet skulle självklart hålla sig med museer och kulturminnesvård - det gällde bevarande och reproduktion av institutionella egenvärden som Folkliv, Historia, Konst och Kultur ${ }^{47}$ - men argumenten för minnesvårdens samhällsrelevans hämtades regelmässigt från ledande forskare och ämbetsmän inom, eller med anknytning till, museisektorn. Museerna tilläts kort sagt "hålla på” med 
sitt utan nämnvärd statlig styrning, vilket i sin tur gav utrymme för den interna museikultur jag anspelar på. Och eftersom museerna själva kunde utforma sitt samhällsuppdrag, kom detta av naturliga skäl att präglas av det som antikvarierna och de artefaktrelaterade forskarna närmast hjärtat: insamling, registrering, dokumentation och utställning i form av visade artefaktsamlingar. Här grundmuras en uppfattning om att museiyrket väsentligen handlar om att rädda, arkivera, ordna och visa "materiell kultur" - tryckta guider till Statens historiska museums utställningar bar, som ett talande exempel, länge namnet Vägledning genom samlingarna. ${ }^{48}$

Prioriterat blir därmed en form av praktisk förtrogenhet med insamlande, katalogisering och visande. Ska man tro Göran Rosander har denna "praktikens" museikultur påverkat kraven på högre utbildning. Han konstaterade i sin studie 1994 att det "är väl känt att museimännens genomsnittliga utbildningsnivå ligger väsentligt lägre i Sverige än i övriga nordiska länder [...], något som generellt bör innebära också lägre forskningskompetens, även om examen och produktionens kvalitet inte nödvändigtvis hänger samman". ${ }^{49}$ Hållningen att museiyrket i första hand fordrar praktisk erfarenhet, blir inte minst tydligt i kriterierna för nyanställning av personal. Rosander åter:

Det är emellertid på sin plats att påpeka de akademiska meriternas ganska ringa värde då man söker tjänst. Ofta föredras yrkeserfarenhet framför teoretiska meriter, något som inte gynnar musievärldens forskningsnivå. Vidare kan man på goda grunder anta att forskarbegåvningarna generellt föredrar en akademisk karriär framför museibanan. På museerna hamnar framför allt praktikerna. ${ }^{50}$

Att Rosander kursiverar visar på att han inte svävar på målet i sin bedömning. Analysen är 121 kanske något onyanserad, men har trots det fog för sig. Det är emellertid viktigt att inse att denna prioritering mot så kallad praktisk yrkeserfarenhet inom museerna inte är naturgiven, utan en konsekvens av institutionell tradition och en kulturpolitik som lämnat frågan om forskning och kunskapsalstring inom museerna helt upp till museerna själva.

Det fordrar inte mycket reflektion för att konstatera att merparten av det som rör museernas verksamhet i grund och botten är diskursivt formerade. Själva idén om att museerna samlar materiella kulturhistoriska spår från det förflutna för framtiden, är späckad av outtalade teoretiska antaganden om vari egentligen kategorin "kultur" består och att denna kultur representeras medelst de artefakter som bevaras. Urvalet för samlande är på inget sätt självklart. Och vidare: i konceptet att genom utställningar förevisa somliga av dessa föremål i sammanhang som aktiverar en intrikat samverkan mellan rum, text, ljussättning, ljud, bild o.s.v., rymmer än fler kluster av sociala, klass-, etnicitets- och genusrelaterade förförståelser om människan i historisk belysning. Inget av dessa värderingar och uppfattningar har uppstått ur tomma intet, museibranschen är en konsekvens av vetenskapliga praktiker som har formerats med grundklang utifrån den stora frågan om vad det historiskt sett innebär att vara en människa och en samhällsvarelse. Det handlar om humaniora, om våra försök att tolka, att förstå, att skapa sammanhang, om hermeneutik. Att sedan konkret föremålshantering, accessionsföring, konservering, bevarandeåtgärder och andra museigöromål fordrar praktiska kunskaper är en annan sak, de är viktiga delar i yrkesfältets färdighetskrav för att uppnå bevarande och tillgängliggörande, men stannar man med detta missar 
122 man museernas övergripande syfte och samhällsuppdrag.

DIK-förbundets enkätrapport kring läget för "museiforskningen" har nu några år på nacken, men situationen lär knappast ha förändrats, det finns goda skäl att ta deras slutsatser på allvar. I deras rapport efterlyser man att fler museer upprättar en intern forskningsorganisation och en permanent forskningsledartjänst. ${ }^{51}$ Museimän som Sten Rentzhog har också påtalat behovet av regelbunden seminarieverksamhet. ${ }^{52} \mathrm{Om}$ sådant förverkligades skulle det ofta åberopade samarbetet mellan universitet och museer betydligt smidigare realiseras. Ett museum som har en tydlig policy visavi insamling som forskning får en kunskapsorienterad profilering. Det ger i sin tur underlag för beslutsfattare att allokera ekonomiska medel, ${ }^{53}$ och det skapar en arena för akademiskt samtal och kunskapsutbyte. Eller för att citera Stefan Bohmans och Karin Lindvals visioner inför 2000-talet då de påpekade att "utan forskarkompetenta museimän som håller sig à jour med forskningen inom de egna ämnena kan varken forskningsinformation eller ökat samarbete med universiteten fungera”. ${ }^{54}$

DIK-förbundets slutsatser kan sammanfattas som följer: De forskningsutbildade eller intresserade inom personalen som bedriver forskning är idag ofta solitärer. Forskningen bygger därmed på individens intressen och engagemang, vilket är en nödvändig men inte tillräcklig förutsättning för att forskningen ska ge återverkningar på museets officiella agenda. Om forskningen verkligen ska få betydelse och påverka museets verksamhet, måste det till strategiska forskningsprogram som förankras hos museets ledning. Det bör kort sagt finnas idéer och planer för vad museet ska ägna sig åt, vilken art av kompetens som man ska sträva att utveckla vidare. Detta förutsätter i sin tur att museets ledning har en förståelse för betydelsen av teoretisk förkovran bland den egna personalen.

\section{SLUTRESONEMANG OCH FRAMTIDSCENARIO}

En slutsats att dra från det som har presenterats är att museiyrket bör få en mer teoretisk status. Alla museichefer måste kanske inte ha forskarutbildning i sin CV och det är heller inte nödvändigt att vara forskarutbildad för att vara en utmärkt museianställd. Men det bör med skäl uppfattas som en merit och en grund för såväl anställning som lönesättning, att ha genomfört en forskarutbildning; oavsett om anställningen avser föremålsinsamling och vård, landskapsvård, eller undervisnings- och utställningsarbete. Vidare bör det rimligen till en förändring i den museikultur som av tradition har anställt och enbart efterfrågat kompetens i ämnena arkeologi, (traditionell) etnologi och konstvetenskap. Förändringar i den riktningen kan förvisso märkas här och var, men DIK-förbundets statistik från 2004 visade, som bara ett exempel, att inget centralmuseum eller länsmuseum hade någon anställd personal med forskarkompetens i ämnet idéhistoria år 2004. ${ }^{55}$ Forskarutbildade i ämnet historia förekommer sparsamt, på länsmuseerna dominerar arkeologerna. Om museerna ska kunna möta dagens och morgondagens krav på pluralism och en konstruktivistisk och mångdimensionell historieförmedling, bör det övervägas att anställa åtminstone någon person som har sin huvudsakliga eller kombinerade kompetens inom områdena museologi, idéhistoria, antropologi, filosofi, sociologi etc.

Ett lovvärt försöka att råda bot på situationen är Nordiska museets forskarskola som kom till just med anledning att bredda under- 
laget av forskarutbildade museipersonal för kommande chefsposter. Nedan ges ett utdrag från motiveringen för forskarskolan:

År 2000 fanns det bara ett fătal forskarutbildade inom museer och kulturmiljövård. Vid t.ex. landets länsmuseer verkade omkring 550 tillsvidareanställda museimän varav bara 21 var forskarutbildade. Dessa representerade under 4 procent av yrkeskåren och var dessutom ojämnt fördelade över landet. De flesta museer dominerades av personal med examen på högst C- eller i bästa fall D-nivå. Många museer saknade helt forskarutbildad personal. Inte bara kvaliteten på museernas verksamhet kan råka i fara, utan också en stor del av den relation till det omgivande samhället som baseras på museernas expertfunktion. ${ }^{56}$

Från första början bestämde man sig för att inrikta sig på att vidareutbilda redan befintlig museipersonal. Via länsmuseernas samarbetsråd genomfördes en enkätundersökning runt landets museer om att anmäla intresse för forskarstudier. Efter 95 inlämnade svar kunde man med stöd från Riksbankens jubileumsfond och Vitterhetsakademien starta forskarskolan vid slutet av 2001. Med ett underlag på runt 70 inlämnade ansökningar fanns ekonomiska medel att, efter urvalsgranskning, bevilja totalt elva doktorandtjänster, ytterligare två tjänster tillkom 2004. Samtliga doktorander har anställning vid ett museum, men bedriver sin forskarutbildning vid ett närliggande universitet. En kompetensmässigt brett sammansatt styrgrupp ansvarar för forskarskolan och även för tilldelningen av forskartjänsterna.

Går man igenom samtliga avhandlingsämnen noterar man något förvånande att åtminstone fem av de tretton tjänsterna förefaller tillhöra ämnet etnologi, medan bara en är renodlad arkeolog - gissningsvis har ansökningarnas kvalitet avgjort tilldelningarna, före ämnestill- hörighet. Generellt dominerande är studier 123 utifrån artefaktrelaterad empiri, alternativt studier i kulturlandskapets förändringar.

Jag har ingen anledning att ifrågasätta de enskilda studiernas validitet eller kvalitet - de håller säkerligen de akademiska måtten - men det stämmer till eftertanke att ingen studie innefattar forskning utifrån utställningsmediet som tema. Utgår man från den klassiska devisen att museernas samhällsuppdrag är att samla vårda och visa, finns slutsatser att dra kring vilken art av forskning museerna borde vara betjänta av att själva driva. Samling och vård har förvisso i sig länge varit ett lågprioriterat och försummat musealt fält. ${ }^{57} \mathrm{Om}$ samlingarna inte är ordnade och dokumenterade i en sådan utsräckning att de kan användas som ett forskningsmaterial, faller skäligen ett grundmotiv för att hålla kostsamma museimagasin $\mathrm{i}$ trim. Tre av de tretton forskarstuderande lyfter fram metodfrågor inom insamling och vård som en del av studiens målsättning. ${ }^{58}$ Samtidigt är det idag inom "visandet", det förmedlande uppdraget, som debatten och det paradigmförskjutande nytänkandet sker. I relation till det förefaller utbudet från Nordiska museets forskarskola vara magert företrätt.

Det är i sig utmärkt om det diskuteras och forskas kring agrarhistoria och klädesdräkter; kort sagt forskning med utgångspunkt från museernas materiella företeelser. Men borde inte museerna även vara intresserade av att också öka sin kunskap kring utställningsmediet - själva den arena som för majoriteten besökare konstituerar ett museum? Sten Rentzhog anser i sin skrift om museer och forskning att en museiutställning inte ger "samma utrymme för analyserande eller diskuterande som en vetenskaplig avhandling". ${ }^{59}$ Må så vara, om utställningens syfte nu vore att spela på samma epistemologiska arena som den skrivna texten. 
124 Men godtar man den utgångspunkten, faller samtidigt hela grundförutsättningen för museernas samlande, vårdande och visande - varför ska samhället stödja museal utställningsverksamhet, om den kunskap man vinner genom forskning på samlingarna, föreskrivet bättre förmedlas via texter? Rentzhog skulle nog hålla med mig om att den museala utställningen erbjuder något mer än det kunskapsinnehåll enskilda texter förmedlar. Den är en unik arena för interaktivt och upplevelsebaserat lärande. Föremål, bilder, texter, ljud och övrig utställningsstruktur förevisas i det fysiska rummet och aktiverar våra sinnen på ett helt annat vis än det budskap en text $\mathrm{i}$ en bok förmedlar.

Men på vilket sätt förmedlar utställningar kunskap; vad menar vi i det fallet med kunskap; och har vi tillräckliga kunskaper om utställningsmediets kommunikativa potentialer ${ }^{60}$ Får man tro Rentzhog finns här brister: "Alltför ofta bygger undervisning och utställningar på ett magert kunskapsmaterial, inte sällan på gamla kursböcker eller t.o.m. skolböcker. Samlingarna används ofta bara som illustrationer." ${ }^{61}$ Förmodat ofrivilligt anger Rentzhog därmed ett starkt skäl till att det också fordras mer forskning kring utställningen som didaktiskt medium. Detta utesluter självfallet inte behovet av den typ av forskning som Nordiska museets forskarskola i nuläget har premierat (metodfrågor inom insamling och vård är f.ö. även det ett klassiskt museologiskt tema). Museologisk och/eller forskning om kulturarvsbruk är idag ett stadigt växande forskningsfält, nationellt såväl som internationellt. Mycket har redan skrivits, men det finns fortfarande väldigt mycket att klarlägga. Borde inte också någon avhandling kring temat utställning och museers kulturella representation ha ingått i utbudet från Nordiska museets forskarskola?
Jag vill avrunda med några exemplifierande frågor, där utrymmet endast medger en vidhängande litteraturhänvisning, för att antyda något om det museologiska fältets relevans: Vad kännetecknar den "kultur" som kulturhistoriska museer traditionellt visar; och vilken "kultur" visar konstmuseet, det naturhistoriska museet, teknikmuseet? Museets roll för folkbildningen har länge varit ett dominerande motiv för dess samhällsrelevans, men förmedlar museer kunskap, och om så: vilken form av kunskap, och hur sker denna förmedling? Finns det nya sätt att låta artefakterna representera "kultur" (den frågan kan inte besvaras för än vi vet vad och hur de traditionellt har representerat)? Bör museet sträva efter att förmedla det kunskapsinnehåll som texter, artiklar och böcker, traditionellt företräder, eller bör museet kanske formulera en egen form av epistemologi, baserat på visandet av föremål som utgångspunkt för kommunikation? ${ }^{32}$

Utifrån dessa och många andra frågor finns fortfarande mycket att utforska och vinna insikter om, som garanterat skulle gagna museet och dess roll i samhället. Och forskningen behövs såväl inom som utom museets väggar; idealt i samarbete mellan universitet och museer. Att försöka utvinna nya metoder för att förvärva kunskap från museernas samlingar är ett givet tema, som kanske bäst fotas $\mathrm{i}$ en forskning vid museerna, med öppna seminarier och samarbete gentemot universitet. Om inte museernas insamlade källmaterial beforskas, faller själva syftet med deras samlande och vårdande uppdrag. Det fordras därför forskarutbildad personal vid museerna för att tillgängliggöra samlingarna, presentera forskningsresultat och marknadsföra samlingarnas potentialer.

Men museet har också ett visande, ett kommunikativt, uppdrag. Detta förutsätter att 
museerna systematiskt arbetar med frågor kring kulturell/historisk representation och hur detta kommuniceras via artefaktrelaterade utställningar. Ett spännande exempel på vad som redan pågår är Nordiskt Centrum för Kulturarvspedagogik i Östersund. NCK:s fysiska placering är i Östersund och drivs av Jamtli, Föreningsarkivet i Jämtlands län samt Landsarkivet i Östersund. ${ }^{63}$ Detta bara nämnt som ett exempel på ett pågående nätverksbyggande. De museologiska frågor jag angav ovan ger en fingervisning om att historiebruk och kulturarvspedagogik just nu är i färd att förändra museal visualisering på många plan. För den tvivlande rekommenderar jag ett besök på Statens historiska museum och deras nya basutställningar.

I den stundtals infekterade debatt som varit om temat forskning på museer framskymtar ibland en rädsla och protektionism från såväl musealt håll som akademiskt. ${ }^{64}$ Rädslan bottnar möjligtvis bitvis på ett skråtänkande inom nämnda museikultur - när numera ytterst få har högre teoretisk utbildning på museerna skrämmer kanske argument om att fler disputerade bör in och mer forskning bör bedrivas? En annan rädsla grundas avgjort i en uppfattning om konkurrens om forskningsmedlen, som om dagens forskningsfält och möjligheter till forskningsanslag vore statiska storheter att förhålla sig till. Tanken tycks vara att om forskning etableras vid museerna, blir det mindre över för universiteten - och omvänt om mer forskning ska kunna etableras vid museerna, måste denna forskning ta över verksamhet som nu bedrivs vid universiteten. Jag tror inte att den bilden är korrekt åt endera hållet. Universitet kontra museer har olika utgångspunkter visavi forskning och utbildning. Universitetsbaserad forskning har möjlighet att friare granska den museala och kul- turarvsrelaterade diskursen, medan museet å 125 sin sida har en direktare tillgång till sitt specifika källmaterial, och då även möjlighet att bedriva mer långsiktig och systematisk kunskapsuppbyggnad i anknytning till vald profil.

En ökad grad av forskarutbildade och forskning vid museerna skulle i själva verket gynna såväl museer som universitet. Nya forskningsfrågor och fält skulle formeras; forskarutbildade som nu tvingas ut i arbetslöshet på grund av universitetens krympande resurser och utbildningar, skulle få en breddad marknad. Museerna skulle vinna samhällelig och vetenskaplig legitimitet som hotas takt med att samlingarna inte beforskas och att utställningar förekommande baseras på grunda kunskapsunderlag.

Avslutningsvis: Om det verkligen är så att de svenska museerna framöver har behov av "flera hundra personer" ${ }^{65}$ disputerade, borde också det innebära att man öppnar portarna och även anställer forskarutbildade utan tidigare museal yrkesbakgrund. Man skulle exempelvis kunna införa en form av lärlingssystem, liknande det som tidigare gällde för blivande landsantikvarier. ${ }^{66}$ Ett års lärlingstid/provanställning, med gradvis stigande lön, skulle säkerställa behovet av forskarutbildad och praktiskt kompetent personal. Jag menar nu inte att någon skulle vara fullärd $\mathrm{i}$ de museala göromålen efter endast ett års anställning. Men anställer man en disputerad får man också förutsätta att denna har vissa kvalitéer som bland annat innefattar förmåga att snabbt sätta sig in i nya frågeställningar och arbetsuppgifter. En disputerad har visat prov på att själv kunna formulera ett vetenskapligt problem; har lärt sig att värdera kunskap (dess möjligheter och begränsningar); har själv under lång tid arbetat kreativt, källkritiskt, och systematiskt med sitt projekt; har deltagit i och upp- 
126 rättat lärda nätverk; har visat prov på god förmåga att uttrycka sig i tal och skrift; har gett prov på djupa kunskaper inom ett område, vilket också ger en förmåga att bedöma andra kunskapsfält. Uppräkningen skulle kunna fortsätta, men min poäng är nog tydlig. Museer behöver forskarutbildade i en framtid. All personal måste självfallet inte vara doktorsutbildad, men helst någon eller några vid samtliga större museer i landet.

\section{NOTER}

1. Erik Hofrén citerad i Göran Rosander, Samla, vårda, visa - eller något mer?: Om museernas kulturpolitiska roll, Statens kulturråd, 1978, andra upplagan 1979, s. 35. Det kan noteras att Hofrén här uppenbart yttrar sig i den kontext av gryende "gräv-där-du-står-rörelse" som vid slutet av 70-talet var högaktuell.

2. Somligt känns dock mindre gångbart. Rosanders utläggningar om museets roll för nationell och etnisk identitet klingar med direkta lån direkt från epoken Sigurd Curman under 1900-talets första decennier. Att kulturarvet "fungerar som en bekräftelse på att man tillhör en grupp med gemensam historia", låter sig inte yttras med förbehållslöst gillande idag. Rosander skrev dock sin skrift i ett annat tidsskede, före att den postmoderna konstruktivismen pekat på problemen med att okritiskt hänvisa till kollektiva gemenskapskriterier.

3. Fredrik Svanberg, Museer och samlande, The Museum of national antiquities, Studies 12 (Stockholm, 2009).

4. Minne och bildning, SOU 1994: 51, s. 115. Notera att Naturhistoriska riksmuseet utgör ett undantag - här avsätts mer an halva kostnadsbudgeten till forskning. Se Kulturpolitik, Regeringens proposition 1996/97: 3, s. 133

5. Tillbaka till gå? Enkätundersökning om forskning och forskarkompetens på museer 2004-03-01, Rapport från DIK Museimannaförbundet, s. 17

6. Minne och bildning, SOU 1994: 51, s. $29 \mathrm{f}$.

7. Betänkandet Minne och bildning, SOU 1994: 51, angav i sin museidefinition inget om vare sig utbildningsnivå, eller att anställda ska bedriva forskning. Allt i syfte att bredda museidefintionen (och därmed sänka de tidigare professionella anspråken). Se del 1, s. $42 \mathrm{f}$.

8. Forminnesvårdskommitténs betänkande, SOU 1922: 12, s. $167 \mathrm{ff}$.

9. Göran Rosander tillhörde kategorin "universella" museimän; arbetade som landsantikvarie i Jämtlands län 1967-91, första intendent vid Nordiska museet och fil dr. och tf professor i etnologi vid Uppsala universitet vid slutet av 80-talet. Rosander var en av de centrala initiativtagarna bakom SAMDOK-verksamheten med sekretariat vid Nordiska museet, skriftställare, kulturpolitiskt engagerad och sakkunnig, och kort sagt både djupt teoretiskt/vetenskapligt och praktiskt intresserad av museernas kulturhistoria. Rosander var anhängare av uppfattningen att museer skulle skapa opinion, inte bara skildra den. Se Rolf Kjellström \& Gunnar Ternhag, Museer som minnen - minen av museer: Seminarium till minne av Göran Rosander (Stockholm, 1999).

10. Minne och bildning, SOU 1994: 51, Bilagedelen, s. 46 .

11. Ibid., s. 51 .

12. Om bakgrund och orsaker till detta paradigmskifte, se Richard Pettersson, Blick för kultur: Idéhistoriska aspekter på etnologisk och arkeologisk kulturforskning i Sverige under 1900-talet (Umeå, 2004).

13. Minne och bildning, SOU 1994: 51, Bilagedelen, s. 52.

14. Se Richard Pettersson, Fädernesland och framtidsland: Sigurd Curman och kulturminnesvardens etablering (Umeå 2001), kapitel 8.

15. Se Minne och bildning, Bilagedelen, s. 76. 
16. Rentzhog, Forskning och museer, s. 71.

17. Tillbaka till gå?, s. 9.

18. Ibid., s. 4.

19. Det kan noteras att museiutredningen 1994 genomförde en enkät till 1100 museianställda runt landet. På frågan "Vad är Ditt huvudsakliga arbetsområde", hade $12 \%$ kryssat för kategorin Forskning och dokumentation. Hur stor del av detta som avsåg renodlad dokumentation och föremålshantering framgår dock inte, ej heller den totala svarsfrekvensen på enkäten! De tolv procenten kan ställas mot att $17 \%$ hade kryssat för att de huvudsakligen arbetade med pedagogisk verksamhet. Minne och bildning, del 1, s. $182 \mathrm{f}$.

20. Minne och bildning, s. 114.

21. Minne och bildning, Bilagedelen, s. $155 \mathrm{ff}$.

22. Sven Nilsson, Kulturpolitikens nya vägar: Kultur, kulturpolitik och kulturutveckling i Sverige (Malmö 2003), s. 241ff.; Richard Pettersson, Den svenska kulturmiljövårdens värdegrunder: En idéhistorisk bakgrund och analys (Umeå, 2003).

23. Göran Rosander, Samla, vårda, visa - eller något mer?: Om museernas kulturpolitiska roll, Statens kulturråd, 1978, s. 10.

24. Minne och bildning, SOU 1994: 51, del 1, s. $42 \mathrm{f}$.

25. Ibid. s. 27.

26. ICOMS nuvarande definition http://icom.museum/statutes.html\#3, den 6 augusti 2008.

27. I Nordstedts Stora engelsk-svenska ordbok från 1994 anges uppslagsordet "research" i första hand betyda forskning. Som andra tolkning anges dock: "2. research, journalistisk, bakgrundsundersökning." Tillsynes valde museiutredningen den journalistiska tolkningen av begreppet, vilket dock inte på något sätt kommenteras i betänkandet.

28. Minne och bildning, SOU 1994:51, del 1, s. 2931.

29. Ibid. s. 29.

30. Ibid., s. 196.

31. Kulturpolitik, Regeringens proposition 1996/97, s. 135.

32. Ett lyft för forskning och innovation, Regeringens propposition 2008/09:50, s. 260f.

33. Signe Margarete Eberhart Sörensen, "Den museale forsknings fremtidsudsigter", i Nordisk museologi 2008: 1-2, s. 210.

34. Sten Rentzhog, Forskning och museer: En debattskrift om museernas behov av kunskap och forskningens behov av museer (Stockholm, 2006), s. 63.

35. Minne och bildning, SOU 1994:51, Bilagedelen, s. 59.

36. Se exempelvis Anders Ekström, ”Den falska återkomsten: Om gammal och ny kulturhistoria", i idem., Representation och materialitet: Introduktion till kulturhistorien (Nora, 2009).

37. Ibid. s. 60.

38. Se, för att bara ta ett exempel i floran, Joakim Molander, Vetenskapsteoretiska grunder: Historia och begrepp (Lund, 2003), s. 130ff. Det bör tilläggas att Poppers s.k. falsifikationism har mött hård kritik i sitt anspråk på att förklara hur vetenskapliga utsagor kommer till. Forskare som Imre Lakatos, Thomas Kuhn och Paul Feyerabend (för att nämna de tre mest prominenta) har pekat på att den vetenskapliga processens faktaproduktion aldrig kan frikopplas från samhällsideal, forskarsamhälle, förutfattade meningar, prestige, och inte minst slumpartade faktorer.

39. Se Richard Pettersson, Blick för kultur: Idéhistoriska aspekter på etnologisk och arkeologisk kulturforskning i Sverige under 1900-talet (Umeå, 2004).

40. "Kompetensfordringar och normalinstruktion för landsantikvarier”, Svenska museer 1933:1, s. 3. Det bör noteras att benämningarna provinsmuseer och länsantikvarier, respektive länsintendenter, fortsatte att vara gångbara under flera decennier framöver.

41. Se exempelvis Evert Baudou, Gustaf Hallströmarkeolog i världskrigens epok (Stockholm, 1997). 
128 42. Se Billy Ehn \& Orvar löfgren, Vardagslivets etnologi: Reflektioner kring en kulturvetenskap (Stockholm 1996); Richard Pettersson, Blick för kultur: Idéhistoriska aspekter på etnologisk och arkeologisk kulturforskning i Sverige under 1900-talet (Umeå, 2004).

43. Agneta Lilja, Föreställningen om den ideala uppteckningen (Uppsala, 1996), s. 62.

44. Orvar Löfgren, ”Ett ämne väljer sin väg”, i Folklivsarkivet i Lund 1913-1988, (Lund, 1988), s. $162 f$.

45. Lennart Holm, ”Distributionsstrategi för kulturkonsumenter", i Museiperspektiv: 25 artiklar om museerna och sambället, Rapport från statens kulturråd 1986: 2.

46. Se Sven Nilsson, Kulturens nya vägar, s. $250 \mathrm{f}$.

47. Svante Beckman, "Vad vill staten med kulturarvet", i Kulturarvet, museerna och forskningen: Rapport frän en konferens, Riksbankens jubileumsfond, 1999, s. 48f.

48. Fredrik Svanberg, Museer och samlande, s. 58.

49. Minne och bildning, Bilagedelen, s. 75 .

50. Ibid, s. 75.

51. Tillbaka till gå?, s. $19 \mathrm{f}$.

52. Rentzhog, Forskning och museer, s. 64.

53. Se exempelvis Barbro Bursell, "Professionalising collecting", i Museum and the future of collecting, second ed. (Leichester, 2005), s. 206.

54. Stefan Bohman och Karin Lindvall, "Museerna i samhället och samhället i museerna", i Museer och kulturarv, red Lennart Palmqvist \& Stefan Bohman (1997) rev. uppl. (Stockholm, 2003), s. 90

55. Tillbaka till Gå?, s. 13.

56. Ur dokumentet "Forskarskolans bakgrund", Nordiska museets hemsida: http://www.nordiskamuseet.se/ Den 30 oktober 2008.

57. Se exempelvis Barbro Bursell, "Professionalising collecting", i Museum and the future of collecting, second ed. (Leichester, 2005), s. 205.

58. De tre: Bo Larsson, "Lokal teknik - lokalt företagande"; Marianne Larsson, "Postens uniforme- ring - i reglementen och vardagspraktik"; Anneli Palmsköld, "Hängkläden, drättar, lister och takdukar - om produktion, bruk och tolkning av folkliga textilier från Halland.”

59. Rentzhog. Museer och forskning, s. 26.

60. Temat har på senare tid engagerat, kanske främst, engelska forskare. Se Eliean Hooper-Greenhill, Museum and Education - purpose, pedagogy, performance Routledge, London/New York 2007.

61. Rentzhog, s. 26.

62. Se artikel och litteraturhänvisning: Kerstin Smeds, "Vad är museologi?", i Rig 2007: 2.

63. Se hemsida: http://www.nckultur.org

64. Se exempelvis debatt mellan professor Kerstin Smeds och ett antal företrädare för museibranschen i DIK-forum under 2004.

65. Rentzhog, Forskning och museer, s. 57.

66. Praxisförfarandet att blivande landsantikvarier skulle ha tjänstgjort vid Statens historiska museum eller Nordiska museet angavs för första gången som normalinstruktioner, i "Kompetensfordringar och normalinstruktion för landsantikvarier", Svenska museer 1933:1, s. 3. Tillägas bör att man här enades om kravet lägst fil. kand. examen som teoretiskt anställningskrav. Detta höjs dock till förordan om lägst fil. lic-examen, alltså forskarexamen, i utredningen om Landsantikvarieorganisationen SOU 1954:26, s. 65.

\section{REFERENSER}

Baudou, Evert, Gustaf Hallström - arkeolog i världskrigens epok (Stockholm, 1997).

Beckman, Svante, "Vad vill staten med kulturarvet", i Kulturarvet, museerna och forskningen: Rapport frän en konferens, Riksbankens jubileumsfond, 1999.

Bohman, Stefan och Lindvall, Karin, "Museerna i samhället och samhället i museerna", i Museer och 
kulturarv, red Lennart Palmqvist \& Stefan Bohman (1997) rev. uppl. (Stockholm, 2003).

Bursell, Barbro, "Professionalising collecting", i $M u$ seum and the future of collecting, second ed. (Leichester, 2005).

Eberhart Sörensen, Signe Margarete, "Den museale forsknings fremtidsudsigter", i Nordisk museologi 2008:1-2.

Ehn, Billy \& Löfgren, Orvar, Vardagslivets etnologi: Reflektioner kring en kulturvetenskap (Stockholm 1996).

Anders Ekström, "Den falska återkomsten: Om gammal och ny kulturhistoria", i idem., Representation och materialitet: Introduktion till kulturhistorien (Nora, 2009).

Ett lyft för forskning och innovation, Regeringens propposition 2008/09:50.

Forminnesvårdskommitténs betänkande, SOU 1922:12.

"Forskarskolans bakgrund", Nordiska museets hemsida: http://www.nordiskamuseet.se/ Den 30 oktober 2008 .

Holm, Lennart, "Distributionsstrategi för kulturkonsumenter", i Museiperspektiv: 25 artiklar om museerna och sambället, Rapport från statens kulturråd 1986:2.

Hooper-Greenhill, Eliean, Museum and Educationpurpose, pedagogy, performance Routledge, London/New York 2007.

ICOMS museidefinition http://icom.museum/statutes.html\#3, den 6 augusti 2008.

Kjellström, Rolf \& Ternhag, Gunnar, Museer som minnen - minen av museer: Seminarium till minne av Göran Rosander (Stockholm, 1999).

"Kompetensfordringar och normalinstruktion för landsantikvarier", Svenska museer 1933:1.

Kulturpolitik, Regeringens proposition 1996/97.

Landsantikvarieorganisationen SOU 1954:26,

Lilja, Agneta, Föreställningen om den ideala uppteckningen (Uppsala, 1996).

Löfgren, Orvar, ”Ett ämne väljer sin väg”, i Folk- livsarkivet i Lund 1913-1988, (Lund, 1988).

Minne och bildning, SOU 1994:51.

Molander, Joakim, Vetenskapsteoretiska grunder: Historia och begrepp (Lund, 2003).

Nilsson, Sven, Kulturpolitikens nya vägar: Kultur, kulturpolitik och kulturutveckling i Sverige (Malmö 2003).

Pettersson, Richard, Blick för kultur: Idéhistoriska aspekter på etnologisk och arkeologisk kulturforskning $i$ Sverige under 1900-talet (Umeå, 2004).

Pettersson, Richard, Fädernesland och framtidsland: Sigurd Curman och kulturminnesvardens etablering (Umeå 2001).

Rentzhog, Sten, Forskning och museer: En debattskrift om museernas behov av kunskap och forskningens behov av museer (Stockholm, 2006).

Rosander, Göran, Samla, vårda, visa - eller något mer?: Om museernas kulturpolitiska roll, Statens kulturråd, 1978, andra upplagan 1979.

Smeds, Kerstin, "Vad är museologi?", i Rig 2007: 2. Svanberg, Fredrik, Museer och samlande, The Museum of national antiquities, Studies 12 (Stockholm, 2009).

Tillbaka till gå? Enkätundersökning om forskning och forskarkompetens på museer 2004-03-01, Rapport från DIK Museimannaförbundet.

${ }^{*}$ Richard Pettersson, Fil dr./Phd; Docent/ Research

Address: Institutionen för kultur-och medievetenskaper/ Museologi

Umeå universitet

S-90187 Umea

Sweden

E-mail: richard.pettersson@kultmed.umu.se 